\title{
Value Innovation by Creating Blue Oceans
}

\author{
Thomas Hammer (1) \\ International School of Management, Frankfurt am Main, Germany \\ Email: thomas.hammer@ism.de
}

How to cite this paper: Hammer, $\mathrm{T}$. (2022) Value Innovation by Creating Blue Oceans. Open Access Library Journal, 9: e8379.

https://doi.org/10.4236/oalib.1108379

Received: January 17, 2022

Accepted: February 8, 2022

Published: February 11, 2022

Copyright () 2022 by author(s) and Open Access Library Inc.

This work is licensed under the Creative Commons Attribution International License (CC BY 4.0).

http://creativecommons.org/licenses/by/4.0/

\begin{abstract}
This text will explain to the reader how important it is for companies to create "Value Innovation" and to find "Blue Oceans". It is shown on 3 examples, how the customer can be made "addicted" to all-in-one services or platforms and how the customer accepts a high price elasticity due to convenience. It will be explained, how creating "Blue Oceans" will result in having almost no competition and how customer-centric orientation and value creation are related to this strategy and how the term "Disruptive Innovation" differs from it. The text also defines the terms "Red" vs. "Blue" Oceans and gives a brief history of this sector.
\end{abstract}

\section{Subject Areas}

Innovation Management

\section{Keywords}

Blue Ocean, Innovation, Value Innovation

\section{Introduction}

"Value innovation is the cornerstone of blue ocean strategy. We call it to value innovation because instead of focusing on beating the competition, you focus on making the competition irrelevant by creating a leap in value for buyers and your company, thereby opening up new and uncontested market space. Value innovation places equal emphasis on value."

W. Chan Kim, Renée Mauborgne (2015)

In today's competition between companies, market power has shifted from suppliers to consumers and global competition is becoming fiercer. Corporate managers in almost all industries are therefore facing major challenges in the future [1]. To reverse the current status quo, they must be consistently innovative in the development and implementation of their competitive strategies. But 
long-term corporate success cannot be achieved through competitiveness alone [2].

It will increasingly depend on the ability of companies to generate "new demand" and create and conquer "new markets" ("Blue Oceans"). The profits generated in the event of (new) market creation are enormous for companies. A good example is the US tech giants Apple and Microsoft. Over the past 15 years, Apple has introduced a large number of successful, innovative products such as the iPod, iTunes, the iPhone, the App Store and the iPad. What is impressive is that since the launch of the iPod in 2001, Apple's market capitalization on the NASDAQ (Technology Exchange in the US) has more than 75 times increased by the end of 2014. Over the same period, Microsoft's stock market value rose by just $3 \%$. With nearly $80 \%$ of the profits from the two "old" business lines Windows and Office, Microsoft has an enormous risk of losing its market share due to a lack of innovations in recent years [2].

In a survey of more than 100 start-ups, Harvard scientists Kim and Mauborgne found that $86 \%$ of the companies classified as start-ups were effectively competing on the market. In other words, it was a gradual improvement in the existing market, such as the introduction of another product line. These "market-compliant" launches generated $39 \%$ of the profits. In contrast, the remaining $14 \%$ of the effectively "new" launches that created or newly created markets generated $61 \%$ of the remaining profits. Consequently, "real blue oceans" offer the real potential for future profitable growth [3].

\section{Term Definition of the Different “Oceans": Red vs. Blue Ocean}

"The only way to beat the competition is to stop trying to beat the competition. Imagine a market universe composed of two sorts of oceans: red oceans and blue oceans. Red oceans represent all the industries in existence today. This is the known market space. Blue oceans denote all the industries not in existence today. This is the unknown market space" [2].

In red oceans, there are defined industry boundaries and the competition rules are well known. In this, e-markets the competitors try to compete with each other to reach a larger part of the existing demand. As these marketplaces are overcrowded and very competitive, the potential for profit and growth decreases. Displacement competition makes the red ocean bloody.

Blue oceans, on the other hand, are characterized by untapped market areas, a great opportunity for increased demand and the opportunity for profitable growth. Irrespective of the fact that some blue oceans emerge beyond existing industry boundaries, most of them are created from the red oceans by expanding existing industry boundaries. In the blue oceans, competition plays no role, as it is an unoccupied marketplace where the rules of the game have yet to be defined. However, the difficult part is that blue oceans are largely unknown [4].

The term blue oceans are new, but their existence is not. They are part of 
business life, past and present. If we look back over the last centuries, we can see that many industries such as automotive, music, aviation, healthcare and management consulting were partly completely unknown or at an early stage of their development [5]. But looking back just a few decades, we find trillion-dollar industries such as e-commerce, smartphones, laptops, biotechnology, and discount retailing that did not exist before (Figure 1)

\section{History of 60 Years Strategy Buzzwords and the Term Blue Ocean}

Executives are overwhelmed with bestselling ideas, buzzwords and best practices to gain competitive advantage for their businesses. However, many of these tools are contradictory [6]. You need to consider whether size, speed, adaptability, or the creation of a blue ocean is the most important thing. In a business environment that is changing faster and faster and more complex than ever before, choosing the right strategy is a critical success factor. The number of strategic tools and frameworks from which executives can choose has risen dramatically since the introduction of business strategy in the early 1960s [7]. And the answers to how these approaches relate to each other or when they should and should not be used are far from obvious [8].

The following figure gives an overview of the strategy buzzwords from 1958 to 2013. "Blue Ocean" was introduced to the business world in 2005 by INSEAD scientists Kim and Mauborgne. Since then, the buzzword "Blue Ocean" with "Disruptive Innovation" by Clayton Christensen [9] has been competing for sovereignty in the interpretation of future strategy and innovation (Figure 2).

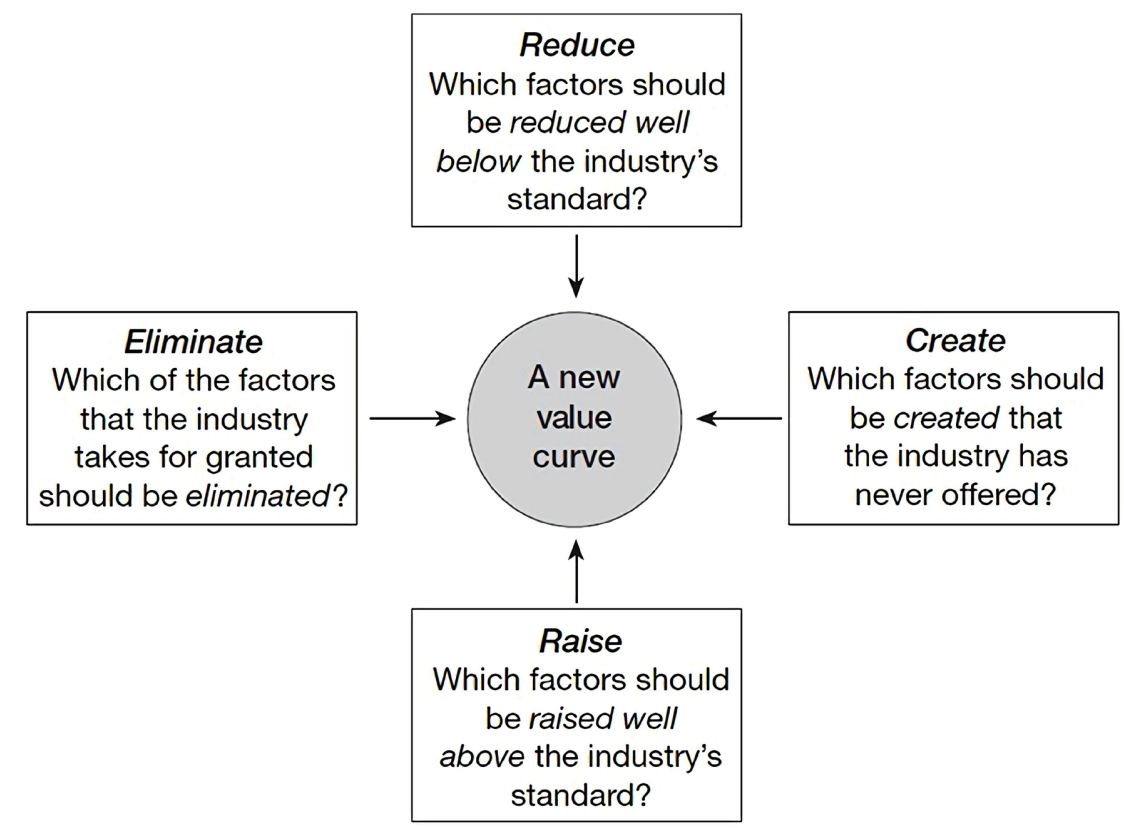

Figure 1. "The four actions framework", Source: Kim, W. Chan and Mauborgne, Reneé, Blue Ocean Strategy, How to Create Uncontested Market Space and Make the Competition Irrelevant, Expanded Edition, (Boston: Harvard Business Review Press, 2015). 


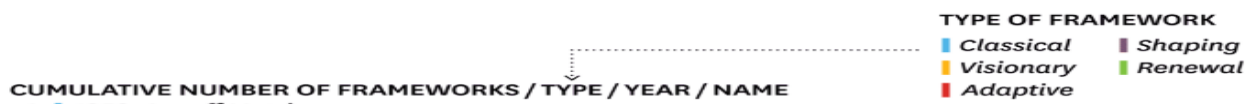

CUMULATIVE NUMBER OF FRAMEWORKS / TY"̈PE / YEAR / NAME

I Shaping

Adaptive

2 III 1959 Industrial Organization

3 III 1962 Diffusion of Innovations

4 IIIII 1962 Scenario Planning

5 IIIIII 1962 Strategy and Structure

6 IIIIIII 1965 Gap Analysis

7 IIIIIII 1965 Product Lifecycle

8 IIHUII 1967 PEST

9 Hнини! 1968 Experience Curve

10 IIIIHIIII 1969 SWOT Analysis

11 IIIHIHIII 1970 BCG Portfolio Matrix

12 แнинини 1971 Andrews's Strategy Framework

13 Iнининии 1973 Red Queen Effect

14 IHнHнини 1974 PIMS (Profit Impact of Market Strategies)

15 Hнининини 1976 Real Options

16 інинининин 1976 Rule of Three and Four

17 нининин 1978 Deliberate and Emergent Strategies

18 แнинининини 19795 Forces

19 Hнинининииіи 19804 Phases of Strategy

20 нининининини 1980 Logical Incrementalism

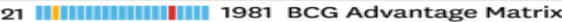

22 Ннинининини 1982 3Cs

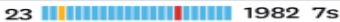

24 нинининининини 1982 Diversification Strategy and Profitability

25 інинининининини 1982 Niche Strategy

26 нининининининини 1982 Technological Paradigms and Technological Trajectories

27 Ннининининининини 1982 TQM

28 нининининининин 1984 Resource-Based View

29 Ннинининининининин 1986 Fishbone Diagram

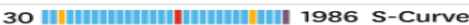

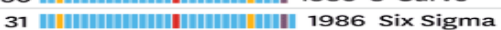

32 แнинининининининини! 1987 Mintzberg's 5 Ps

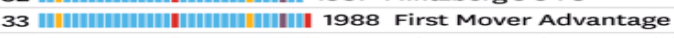

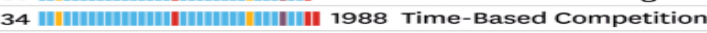

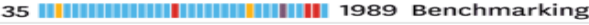

36 แнинининининининини 1989 Core Competencies

37 инининининининининини 1990 Diamond Model

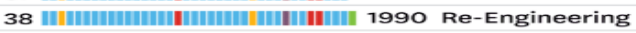

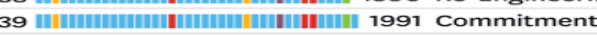

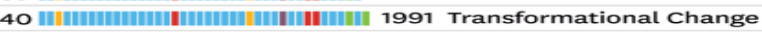

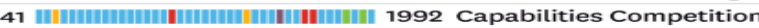

42 Нининининининининининини| 1992 Mass Customization

43 нининининининининиининии 1993 Ecosystem Strategy

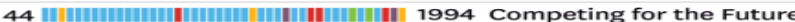

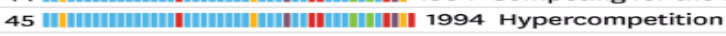

46 нининининининининининининин| 1995 Disruptive Innovation

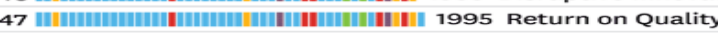

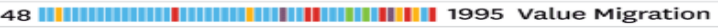

49 ॥ण

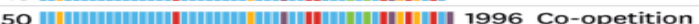

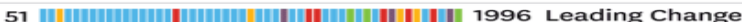

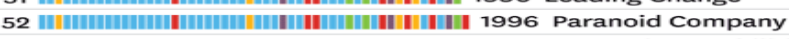

53 нинининининининининининининини 1997 Dynamic Capabilities

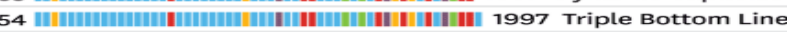

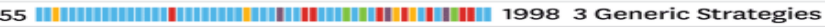

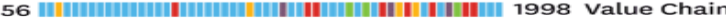

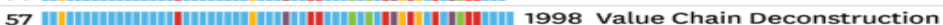

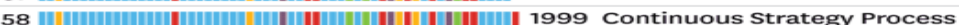

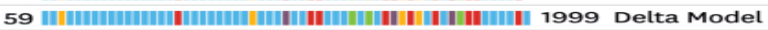

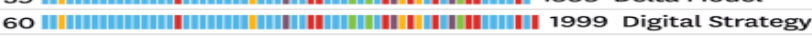

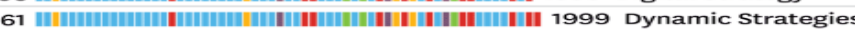

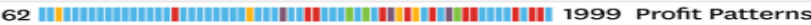

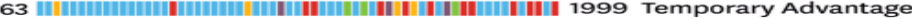

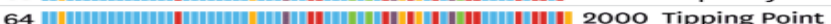

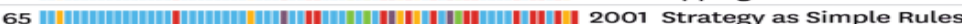

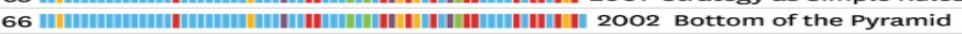

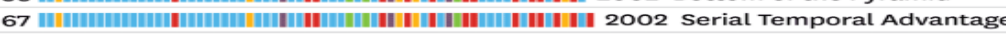

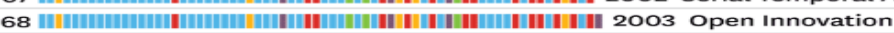

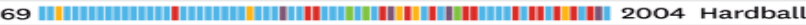

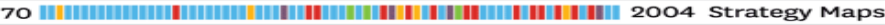

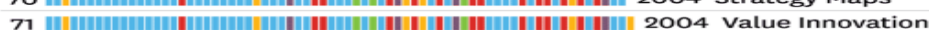

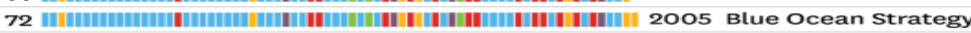

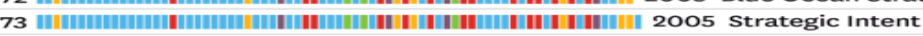

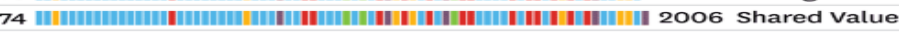

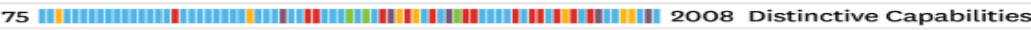

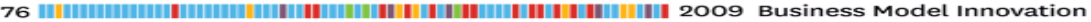

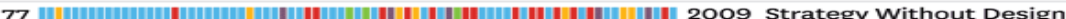

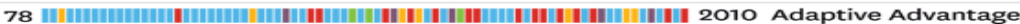

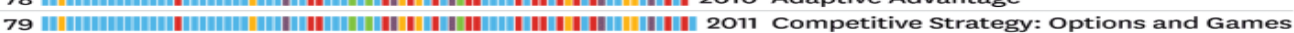

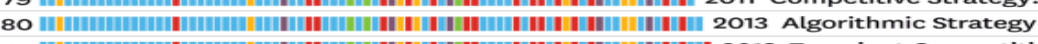

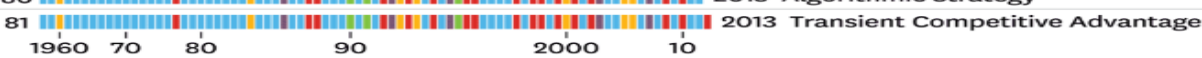

Figure 2. "The number of strategy frameworks has skyrocketed over time", Source: Harvard Business

Review Press, Boston 2015, research by The Boston Consulting Group Strategy Institute. 


\section{Identify "Blue Oceans"}

The Marketing division in enterprises has attached great importance to identifying and conquering niche markets through ever-finer market segmentation [10]. Although niche strategies can often be very effective, it is not the same thing to discover a niche in an existing space as to identify a new marketplace. Successful market-creating strategies do not focus on finer segmentation. More frequently, they "desegment" markets by identifying important commonalities between buyer groups that could lead to broader demand [11].

The first principle of the blue ocean strategy is the redesign of market boundaries to break out of the competition and create blue oceans. This principle considers the risk potential of the search, with which many enterprises have to deal. The challenge is to successfully identify commercially compelling blue ocean opportunities from the stack of existing opportunities. Companies must develop a strategic view of alternative industries, strategic groups, buyer groups, complementary product and service offerings, the functional and emotional positioning of industry and, in particular, the (short-term) time horizon. This gives organizations a deep insight into the redefinition of market realities and the development of blue oceans [11].

There are six basic approaches to redefining market boundaries. These approaches can be applied across industries and lead companies into the field of commercially applicable blue ocean ideas.

\subsection{Alternative Industries}

Companies compete not only with the other firms in their industry but also with companies in those other industries that produce alternative products or services [12]. Alternatives are broader than substitutes. Products or services that have different forms but offer the same functionality or core utility are often substitutes for each other. Alternatives could include products or services that have different functions and forms but the same purpose. By focusing on key factors that encourage buyers to consume through alternative industries, blue oceans with new marketplaces can be created [13].

\subsection{Strategic Groups within Industries}

Blue oceans can be explored not only by looking at alternative industries but also by looking at strategic groups. The term refers to a group of companies within an industry that pursue a similar strategy. The majority of industries are dominated by a small number of strategic groups [14]. The key to creating a blue ocean across existing strategic groups is to break out of this tunnel view by understanding which factors determine customer decisions that lead to a change from one group to the other [15].

\subsection{Chain of Buyers}

In the majority of industries, competitors have a common definition of what the 
target buyers are. In reality, however, there is a "chain of buyers" who are directly or indirectly involved in the purchase decision. The buyers who pay for the product or service may be different from the actual users and in some cases "influencers" contribute significantly to the purchase decision [16]. Although these three groups may overlap, they often differ. They frequently have different value drivers for their purchasing decision [17].

\subsection{Complementary Product and Service Offerings}

Only a few products and services and on their basis, in most cases, supplementary products and services influence and increase the overall value of the product offering. Untapped value is often hidden in complementary products and services [15].

\subsection{Functional or Emotional Appeal to Buyers}

Industry competition tends to have a fixed idea of the scope of its products and services. Companies often compete on price and function, especially through utility calculations; the attractiveness of the product is rational and less emotional. The attractiveness of most products or services is usually due to how companies have unconsciously informed consumers in the past about what to expect [18]. When companies are willing to compromise the functional-emotional orientation of their industry, they often find new markets [13].

\subsection{Time Horizon}

All industries are subject to external trends that affect their businesses over time. Think of the rapid rise of the cloud or the global movement toward protecting the environment. Looking at these trends with the right perspective can show you how to create blue ocean opportunities. Most companies adapt incrementally and somewhat passively as events unfold. Whether it's the emergence of new technologies or major regulatory changes, managers tend to focus on projecting the trend itself. But key insights into blue ocean strategy rarely come from projecting the trend itself. Instead, they arise from business insights into how the trend will change the value to customers and impact the company's business model. By looking across time managers can actively shape their future and lay claim to a new blue ocean [17].

\section{Buzzword Competition: Blue Ocean vs. Disruption}

Creative Destruction or Disruptive Innovation occurs when an innovation (often technologically based) breaks up and conquers an existing market by displacing an earlier technology, product or service [19].

The word "displacing" is particularly important in this case, since without "displacing" out there can be no "destruction" (of the existing market and competitors). A very good example is photography. The innovation of digital photography has displaced the traditional photographic film industry and its market participants (Eastman Kodak and Agfa). Today, digital photography is standard 
and traditional film photography is rarely used (or only by professional photographers). One can speak of creative destruction here, based on Schumpeter's concept, because the old is constantly being destroyed or replaced by the new [20]. In contrast to creative destruction, the Blue Ocean Strategy does not require displacement or even destruction. The Blue Ocean Strategy is a much more comprehensive concept that goes beyond creative destruction and has its overarching focus on creation [2].

\section{Blue Ocean: Best Practice Examples; "The Triple-A"}

"The winners will be those brands which have succeeded in convincing consumers with disruptive ecosystems.”

Bernd Büchner, Kantar Germany [21]

Brands make markets and the stronger the brand name and the associated brand value, the easier it is to build and maintain "Blue Oceans". The brand value always reflects the perception of the company and its services by the customer. It can be stated that companies with a strong brand generate less price elasticity with the customer, i.e. the customers are more willing to pay higher prices since the company delivers a high convenience from their point of view and they are willing to pay more for it or use it more frequently [22]. And on the other hand, a strong brand value ensures that customers are more loyal to the company. A ranking of the strongest brands was published in June 2021 by Kantar Germany and BrandZ. It is noticeable that Amazon, Apple and Alibaba stand out with high values. These three companies ("Triple-A") and their innovative strength are briefly described in Table 1 .

\subsection{Amazon}

"Value innovation requires companies to orient the whole system toward achieving a leap in value for both buyers and themselves."

W. Chan Kim, 2015 [23]

Table 1. "The most valuable Global Brands 2021", Source: Bloomberg; BrandZ; Kantar; S\&P Capital IQ [Kantar Germany and BrandZ, p. 20].

\begin{tabular}{cccc}
\hline Rank & Brand & Value 2021 in Bn. USD & Change to 2020 in \% \\
\hline 1 & Amazon & 683.85 & 64 \\
2 & Apple & 612 & 74 \\
3 & Google & 458 & 42 \\
4 & Microsoft & 410.27 & 26 \\
5 & Tencent & 240.93 & 60 \\
6 & Facebook & 226.74 & 54 \\
7 & Alibaba & 196.91 & 29 \\
8 & Visa & 191.29 & 2 \\
9 & McDonald's & 154.92 & 20 \\
10 & Mastercard & 112.88 & 4 \\
\hline
\end{tabular}


How often do customers ask themselves: "Why don't they ask..."? When shopping in a department store, do you make a note of which products are to be added or removed? When it comes to the presentation of the store, think about changing the layout, lighting and perhaps colour. Or the question of service? There is no shortage of suggestions for improvement, is there? The same applies to airlines, telephone companies, banks, every organization you deal with, you constantly redesign strategic factors such as product range, presentation and customer service [15]. Amazon is restless in redeveloping such customer-friendly solutions and creating "Blue Oceans".

Nine years ago, the online retailer Amazon presented its first plans for an autonomously flying delivery drone. Now the "Prime Air" aircraft is ready and will soon deliver parcels within 30 minutes, according to the promise of the US company. With projects such as the delivery drone, Amazon wants to underline its innovative strength. The company tries out many things, tolerates mistakes and even stops projects if necessary [24].

Monthly fee for the use of Amazon that customers would be willing to pay at least or at most in Euros (Figure 3).

\subsection{Apple}

\section{“Create. Don't Compete."}

W. Chan Kim, Renée Mauborgne, 2015 [25]

Several strategic Blue Ocean decisions have made Apple the most valuable and respected company in America within a decade. With the iMac, iPod, iTunes Store, iPhone, and iPad, products from the company's various business units were created that shared a common vision, to reorganize existing markets and create new demand. The most decisive Blue Ocean that Apple has created from the above is especially the iPhone, as it has created a convenience standard for the customers in an existing market of mobile phones and thus has become not only a leader in terms of market share, but especially the decisive revenue generator for Apple. Over time, Apple introduced additional Blue Oceans, including its

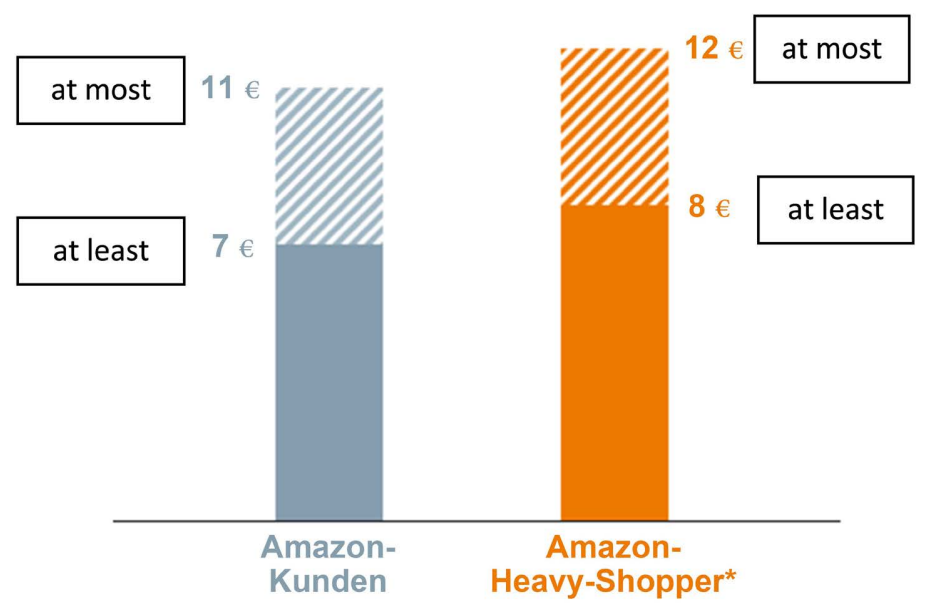

Figure 3. Handelsblatt edition 2nd of July 2019, p. 15/IFH Köln. 
App Store and iPad, to ensure the company's next level of growth, while others began entering the (already established) Blue Oceans and turning them red [25] (Figure 4).

\subsection{Alibaba}

Alibaba is an excellent example of customer-oriented growth. By 2018, Alibaba had grown to become one of the world's largest companies in terms of market capitalization, with more than ten multi-billion dollar companies in a variety of industries including retail, e-commerce, online cloud services, mobile phones, logistics, payments, content and more. The most significant Blue Ocean strategy that Alibaba introduced was Alipay. Alipay has reached a market share of more than $54 \%$ in the Chinese market and has taken a oligopoly position together with Tencents Tenpay (see Figure 5).

In addition to Alipay, Alibaba's Blue Ocean "Singles' Day" has been a relevant success, generating nearly seven times more revenue than Amazon's Prime Day (see Figure 6).

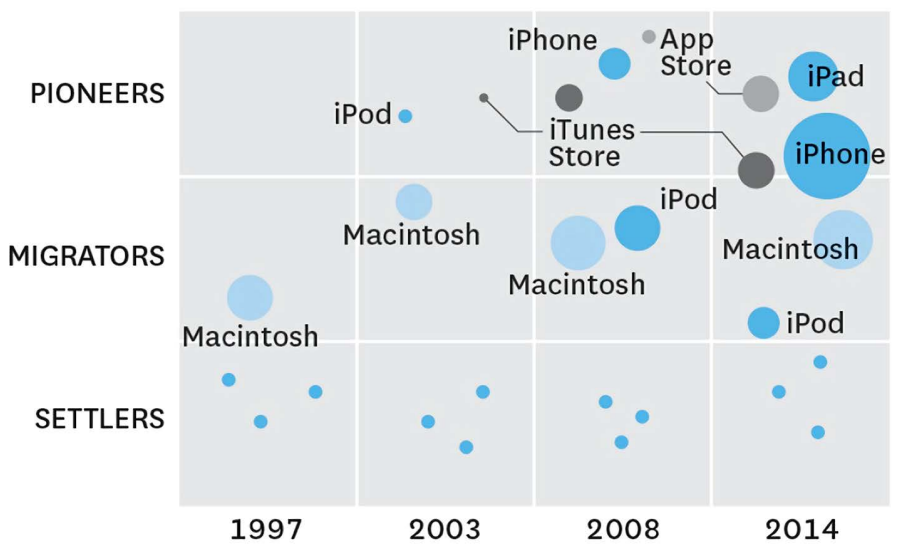

Figure 4. "Apple's portfolio of businesses from 1997 to 2014", Source: Kim, W. Chan and Mauborgne, Reneé, Blue Ocean Strategy, How to Create Uncontested Market Space and Make the Competition Irrelevant, Expanded Edition, (Boston: Harvard Business Review Press, 2015).

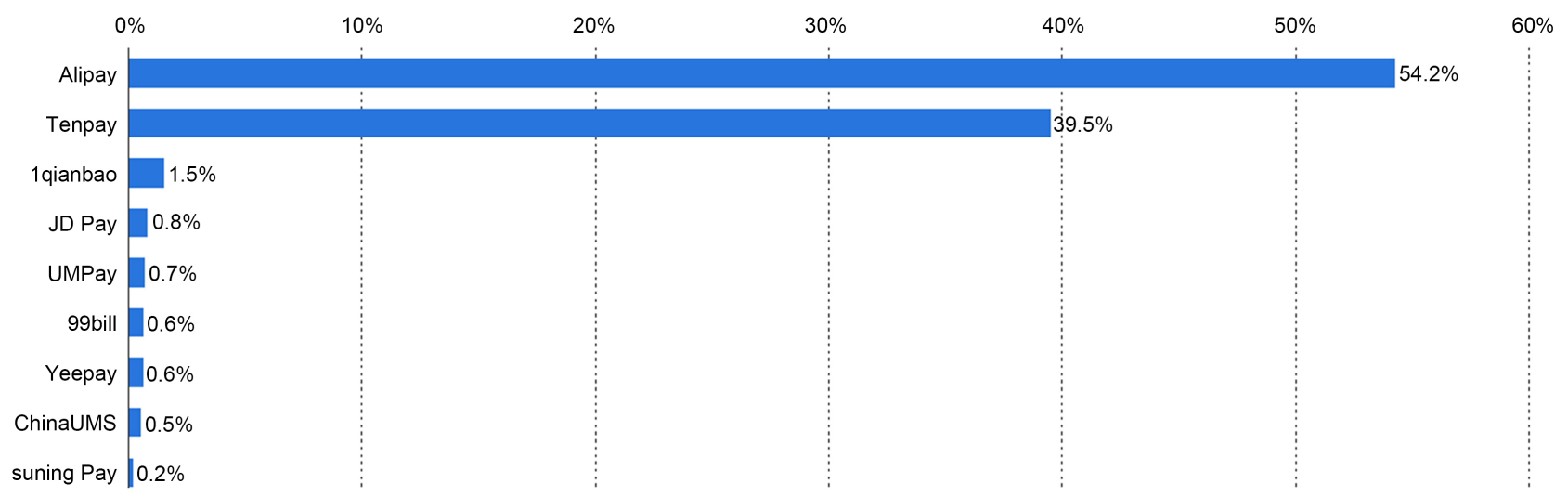

Figure 5. "Market shares of mobile payment providers in China 2019", Market share by transaction, Source: iResearch; October 2019. 
=Prime Day (Amazon) $=$ Singles' Day (Alibaba)

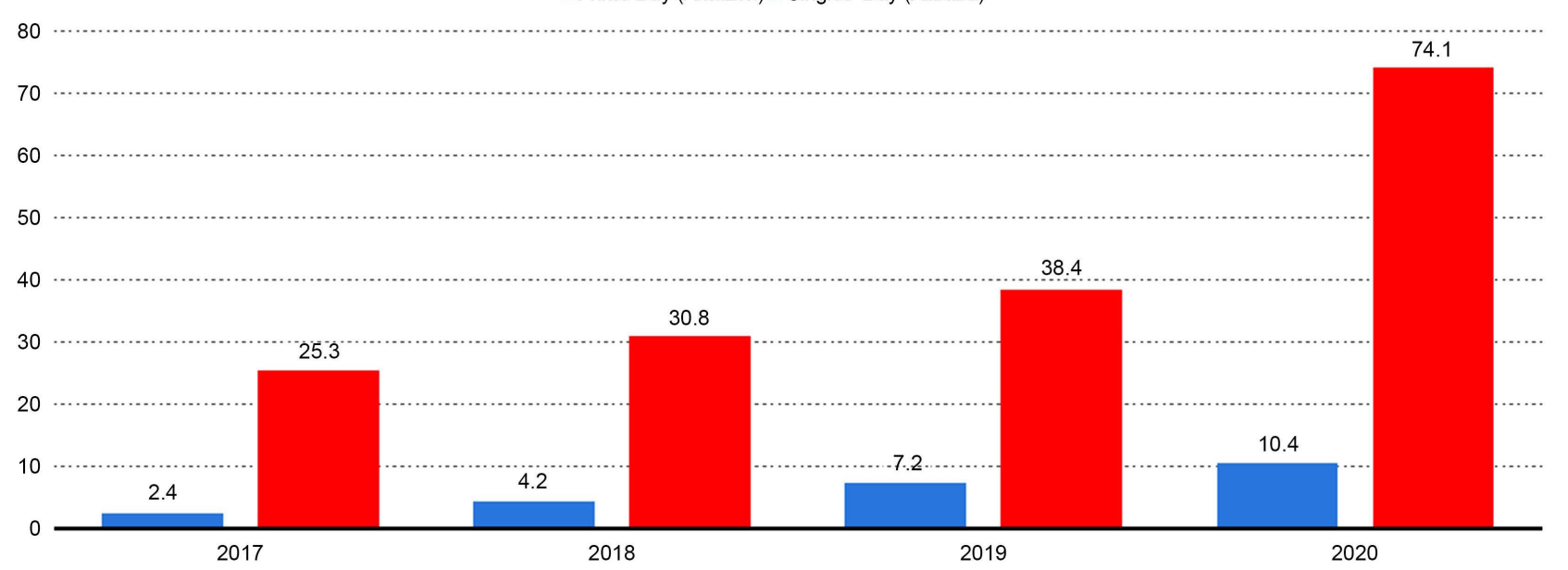

Figure 6. "Worldwide sales of Amazon on Prime Day and of Alibaba on Singles' Day from 2017 to 2020 (in billions of U.S. dollars)", Source: Digital Commerce 360 and CNBC, November 2020.

From 2011 to 2016, the company's revenue grew at an average annual growth rate of $87 \%$. Profit increased by $94 \%$ and cash flow by $120 \%$. Such rapid growth is unique for such a large and established digital company [26]. Alibaba's successful concept is to constantly expand its "customer value" via interlinked platforms, which promotes user convenience. The company is constantly looking for new "Blue Oceans".

\section{Conclusions}

In an ever faster changing business world the so-called "Value Innovation" or finding "Blue Oceans" is essential for the competitiveness of companies. The three examples Amazon, Apple and Alibaba illustrate how customers can be made "addicted" to innovative additional services via a platform that combines all services. The price elasticity on the customer side is reduced and additional consumption is generated. For customers, convenience, and the unconditional focus of all corporate services on them are at the forefront.

A corporate strategy based on generating more and more "Blue Oceans" creates markets for companies that initially (almost) have no competition. The revenues that can be achieved there can be skimmed off until the competition is overwhelming, and the margins are low. These returns, this is the principle of the "Triple-A", are consistently used in the research of further new "Blue Oceans", so that a flywheel is created that repeatedly creates market advantages and often does not allow competition to penetrate or push it out of the market. The customer-centricity of the platform concepts of Amazon, Apple and Alibaba has created this unique market position. Value innovation, customer orientation or "Blue Ocean" all three buzzwords mean the same thing: Creating added value for customers generates "New Markets". The main difference to the competitive slogan "Disruptive Innovation" is that disruption refers to the destruction of an existing market and "Blue Ocean" refers to the generation of a new market that 
has often been "innovated from existing markets" [19].

In conclusion, it should be noted that the buzzword "Blue Ocean" refers to a company's ability to innovate in terms of customer orientation and customer convenience. This customer-centricity creates a brand with which customers associate value in the long term [27]. The brand is the most valuable asset a company owns in the long run.

\section{Conflicts of Interest}

The author declares no conflicts of interest.

\section{References}

[1] Siegfried, P. (2015) Strategische Unternehmensplanung in jungen KMU: Probleme and Lösungsansätze. De Gruyter/Oldenbourg Verlag, Berlin. https://doi.org/10.1515/9783110429022

[2] Chan, K.W. and Reneé, M. (2005) Blue Ocean Strategy-How to Create Uncontested Market Space and Make the Competition Irrelevant. Harvard Business Review Press, Boston.

[3] Chan, K.W. and Reneé, M. (2005) Identify Blue Oceans by Mapping Your Product Portfolio. Harvard Business Review Press, Boston.

[4] Siegfried, P. (2013) Studies Analyse on Strategic Corporate planning in SMEs. Proceedings of the Entrepreneurship Summer University at ISCTE-IUL 2013, Lisboa, 19-23 August 2013, 618-632.

[5] Siegfried, P. (2015) Die Unternehmenserfolgsfaktoren und deren kausale Zusammenhänge, Zeitschrift Ideen-und Innovationsmanagement. Deutsches Institut für Betriebswirtschaft GmbH/Erich Schmidt Verlag, Berlin, 131-137. https://doi.org/10.37307/j.2198-3151.2015.04.04

[6] Siegfried, P. (2014) Knowledge Transfer in Service Researches-Service Engineering in Startup Companies. EUL-Verlag, Siegburg.

[7] Siegfried, P. (2015) Trendentwicklung und strategische Ausrichtung von KMUs. EUL-Verlag, Siegburg.

[8] Reeves, M., Haanaes, K. and Sinha, J. (2015) Navigating the Dozens of Different Strategy Options. Harvard Business Review Press, Boston.

[9] Christensen, C.M. and Overdorf, M. (2000) Meeting the Challenge of Disruptive Change. Harvard Business Review Press, Boston.

[10] Bockhaus Odenthal, E. and Siegfried, P. (2021) Agilität über Unternehmensgrenzen hinaus-Agility across Boundaries. Bulletin of Taras Shevchenko National University of Kyiv, Economics, 3, 14-24, Peer-Review.

[11] Chan, K.W. and Reneé, M. (2015) Blue Ocean Strategy-How to Create Uncontested Market Space and Make the Competition Irrelevant, Expanded Edition, Harvard Business Review Press, Boston.

[12] Bätz, K. and Siegfried, P. (2021) Complexity of Culture and Entrepreneurial Practice. International Entrepreneurship Review, 7, 61-70.

https://doi.org/10.15678/IER.2021.0703.05

[13] Chase, R. (2016) We Need to Expand the Definition of Disruptive Innovation. Harvard Business Review Press, Boston.

[14] Huke, J. and Siegfried, P. (2021) Finance Methods in the Automotive Sec- 
tor-Business Agility in the Age of Digital Disruption. International Journal of Automotive Science and Technology, Peer Review, 5, 281-288. https://doi.org/10.30939/ijastech..955551

[15] Kenny, G. (2014) Customers Are Better Strategists than Managers. Harvard Business Review Press, Boston.

[16] Siegfried, P. (2021). Strategic Management Business Cases and Management Concepts. BoD Book of Demand, Norderstedt.

[17] Donald, S. (2015) Where Disruptive Innovation Came from. Harvard Business Review Press, Boston.

[18] Siegfried, P. (2017) Corporate Strategic Management in Practice. AVM Akademische Verlagsgemeinschaft, Munich.

[19] Christensen, C.M., Raynor, M. and McDonald, R. (2015) What Is Disruptive Innovation? Twenty Years after the Introduction of the Theory, We Revisit What It Does and Doesn't Explain. Harvard Business Review Press, Boston.

[20] Schumpeter, J.A. (1975) Creative Destruction, from Capitalism, Socialism and Democracy. Harper, New York, 82-85.

[21] Büchner, B. (2019) Handelsblatt. Edition of 11th of June 2019. Kantar Publisher, Germany and BrandZ, Berlin, 18.

[22] Seipp, V., Michel, A. and Siegfried, P. (2020) Review of International Supply Chain Risk Within Banking Regulations in Asia, US and EU Including Proposals to Improve Cost Efficiency by Meeting Regulatory Compliance. Journal Financial Risk Management (JFRM), 9, 229-251. https://doi.org/10.4236/jfrm.2020.93013

[23] Chan, K.W. and Reneé, M. (2014) Blue Ocean Leadership. Harvard Business Review Press, Boston.

[24] Gregg, T. and Groysberg, B. (2019) Amazon's Priorities over the Years, Based on Jeff Bezos's Letters to Shareholders. Harvard Business Review Press, Boston.

[25] Chan, K.W. and Reneé, M. (2015) Red Oceans Traps-The Mental Models That Undermine Market-Creating Strategies. Harvard Business Review Press, Boston.

[26] Teixeira, T.S. (2019) Disruption Starts with Unhappy Customers, Not Technology. Harvard Business Review Press, Boston.

[27] Siegfried, P. (2014) International Management: Fallstudien zum Risiko-, Krisen-, Changemanagement and Internationalisierungsstrategien. AVM Akademische Verlagsgemeinschaft, Munich. 